NBER WORKING PAPER SERIES

\title{
THE DIRECT SUBSTITUTION BETWEEN GOVERNMENT AND PRIVATE CONSUMPTION IN EAST ASIA
}

\author{
Yum K. Kwan \\ Working Paper 12431 \\ http://www.nber.org/papers/w12431 \\ NATIONAL BUREAU OF ECONOMIC RESEARCH \\ 1050 Massachusetts Avenue \\ Cambridge, MA 02138 \\ August 2006
}

This paper is forthcoming in Takatoshi Ito and Andrew Rose (eds.) Fiscal Policy and Management in East Asia (NBER East Asia Seminar on Economics, Volume 16), University of Chicago Press. An earlier draft was presented at the NBER 16th East Asian Seminar on Economics, June 23-25, 2005, Manila, Philippines. I am indebted to Gregory Chow, Takatoshi Ito, Mario Lamberte, Charles Leung, Kiyoshi Mitsui, Andrew Rose, and participants of the NBER conference for helpful comments and suggestions. Financial support from the Research Center for International Economics, City University of Hong Kong, and the Center for Economic Development, Hong Kong University of Science and Technology, are gratefully acknowledged. The views expressed herein are those of the author(s) and do not necessarily reflect the views of the National Bureau of Economic Research.

@ 2006 by Yum K. Kwan. All rights reserved. Short sections of text, not to exceed two paragraphs, may be quoted without explicit permission provided that full credit, including $\odot$ notice, is given to the source. 
The Direct Substitution Between Government and Private Consumption in East Asia

Yum K. Kwan

NBER Working Paper No. 12431

August 2006

JEL No. E6, H5

\begin{abstract}
We investigate empirically the extent to which government consumption substitutes for private consumption in nine East Asia countries. Panel cointegrating regression uncovers a significantly positive elasticity of substitution between government and private consumption, implying on average government and private consumption are substitutes in East Asia. Country-by-country analysis, however, reveals diversity in the substitutability estimates. The four North East countries - China, Hong Kong, Japan, and Korea - tend to share similar and moderate values of the substitution elasticity. For the five ASEAN countries studied in this paper, the relationship between private and government consumption vary substantially, both in the sign and magnitude of the elasticity of substitution. Private and government consumption in Malaysia and Thailand are strong substitutes, but they are found to be complements in Indonesia and Singapore. In between is the Philippines which has a near zero elasticity of substitution.
\end{abstract}

Yum K. Kwan

Department of Economics and Finance

City University of Hong Kong

Tat Chee Avenue, Kowloon

HONG KONG

efykkwan@cityu.edu.hk 


\section{Introduction}

An important issue in the design of fiscal policy is the substitutability between government and private consumption. If the private sector derives utility from government-provided goods and services and regards private and government consumption as close substitutes, an increase in government consumption will be offset by a corresponding decrease in private consumption, rendering the size of the fiscal multiplier relatively small and even potentially negative. On the other hand, if private and government consumption are complements, an expansionary fiscal policy will be relatively effective in stimulating aggregate demand as private consumption will reinforce the initial fiscal impulse. While it is easy to give examples of individual private and government goods that are substitutes or complements, it is an empirical question whether aggregate private and government consumption are substitutes or complements for a particular economy during certain period. The purpose of this paper is to empirically study the substitutability issue for nine East Asian countries - the four northeast countries: China, Hong Kong, Japan, and Korea, and the five southeast ASEAN countries: Indonesia, Malaysia, Philippines, Singapore, and Thailand.

Traditional macroeconomic models assume that government consumption works through its impact on private consumption through wealth effect or interest rate effect. Private consumption is crowded out either because the consumers may feel poorer as a result of negative wealth effect or they may be induced to postpone consumption in response to deficit-financed government spending. Bailey (1971) and Barro (1981) first suggest incorporating government consumption into the representative agent decision problem, making the public sector part of the general equilibrium system. The idea is that 
many government goods are to some extent substitutes for private consumption goods. Moreover, government purchases may also serve as useful inputs to the private production function so that government consumption can be productive. This is in contrast to the traditional models in which government consumption are regarded as purely wasteful or unrelated to private consumption or production. In recent theoretical literature, the interaction between government and private consumption has been assigned a central role in the study of fiscal policy, in both the neoclassical real business cycle fashion (e.g. Aiyagari et al. (1992) and Baxter and King (1993)) and the new Keynesian fashion with monopolistic competition, increasing returns, and nominal rigidities (e.g. Devereux et al. (1996) and Ganelli (2003)). However, depending on their assumptions about market structure and technology, these models can predict totally different reaction of private consumption in response to government spending shocks.

On the empirical front, a large literature has been developed to estimate the relationship between government and private consumption. Kormendi (1983) and Aschauer (1985) are representative of the earlier approach that relies on estimating a consumption function. Karras (1994), Ni (1995), Evans and Karras (1996), and Fiorito and Kollintzas (2004) are some of the more recent contributions along this approach. Ni's paper also provides a useful survey of the literature. The empirical analysis in this paper follows Amano and Wirjanto $(1997,1998)$ who make use of the cointegration approach of Ogaki (1992) and Ogaki and Park (1997) to estimate the preference parameter that governs the relationship between government and private consumption. The idea is to exploit the long-run restriction imposed by the intraperiod first-order condition that 
characterizes the optimal choice of private and government consumption. Ho (2001), Chiu (2001), and Okubo (2003) are some recent contributions along the same line.

The rest of the paper is organized as follows. Section 2 presents the empirical model in detail. We provide a structural interpretation to the cointegrating regression model by deriving it as an equilibrium condition. Section 3 provides a brief description of government expenditures in East Asia. The data and empirical results are presented in section 4. Section 5 concludes.

\section{The empirical model}

The empirical work in this paper centers around a cointegrating regression that relates the logarithm of private and government consumption ratio, $C_{t} / G_{t}$, to the logarithm of their relative price $P_{t}^{g} / P_{t}^{c}$ :

$$
\ln \left(C_{t} / G_{t}\right)=\alpha+\beta \ln \left(P_{t}^{g} / P_{t}^{c}\right)+u_{t}
$$

where $\ln \left(C_{t} / G_{t}\right)$ and $\ln \left(P_{t}^{g} / P_{t}^{c}\right)$ are both difference-stationary I(1) processes, and $u_{t}$ is a stationary $\mathrm{I}(0)$ process. Formal statistical evidence for the cointegration property will be provided below. The slope parameter $\beta$ is the elasticity of substitution between private and government consumption. A positive (negative) $\beta$ means that the two goods are substitutes (complements). One attractive feature of cointegrating regression is that the slope parameters can be estimated consistently without the assumption that the regressors 
are econometrically exogenous. In eq. (1), for example, $\beta$ can still be estimated consistently even though there may be stationary omitted variables or measurement errors.

So far eq. (1) is treated as a pure statistical relationship between the consumption ratio of private and government goods and their relative prices. It is possible to provide the equation a structural interpretation by deriving it as an equilibrium condition, following the ideas of Ogaki (1992), Ogaki and Park (1997), and Ogaki and Reinhart (1998). Assume that the representative consumer values two goods, private and government, according to an expected life-time utility function subject to stationary preference shocks:

$$
U=E_{t}\left[\sum_{j=0}^{\infty} \delta^{j} u\left(C_{t+j}^{*}\right)\right]
$$

where

$$
C_{t}^{*}=\left[\phi \varepsilon_{t} C_{t}^{1-(1 / \sigma)}+(1-\phi) \nu_{t} G_{t}^{1-(1 / \sigma)}\right]^{1 /(1-(1 / \sigma)]}
$$

$\left(\varepsilon_{t}, v_{t}\right)$ are random preference shocks which are assumed to be strictly stationary, have unit mean and finite variances. The stationarity assumption amounts to say preferences are stable in the long run. The period utility function is assumed to possess the usual properties $u^{\prime}>0$ and $u^{\prime \prime}<0 .(\phi, \sigma)$ are preference parameters which characterize the representative agent's utility function: $\phi$ is the relative weight assigned to private goods and $\sigma$ is the substitution parameter which measures the curvature of the indifference 
curves. Given time-separability of the utility function, the optimal consumption bundle will have to satisfy the equality between marginal rate of substitution and relative price:

$$
\frac{\partial U / \partial G_{t}}{\partial U / \partial C_{t}} \equiv \frac{v_{t}(1-\phi) G_{t}^{-1 / \sigma}}{\varepsilon_{t} \phi C_{t}^{-1 / \sigma}}=\frac{P_{t}^{g}}{P_{t}^{c}}
$$

Taking logarithm and rearranging yields

$$
\ln \left(C_{t} / G_{t}\right)=-\sigma \ln [(1-\phi) / \phi]+\sigma \ln \left(P_{t}^{g} / P_{t}^{c}\right)-\sigma \ln \left(v_{t} / \varepsilon_{t}\right)
$$

Stable preferences implies that the residual term, $-\sigma \ln \left(v_{t} / \varepsilon_{t}\right)$, is stationary and hence eq.

(5) should be a cointegrating regression, provided that $\log$ consumption ratio, $\ln \left(C_{t} / G_{t}\right)$, and $\log$ price ratio, $\ln \left(P_{t}^{g} / P_{t}^{c}\right)$, are both I(1) processes. In other words, the stable preferences assumption, together with the consumer optimality condition in eq. (4), imposes a cointegration restriction on the movements of the log consumption ratio and the log price ratio series. Eq. (5) provides a structural interpretation to eq. (1) which can be regarded as the reduced form equation with parameters and residuals related to their structural counterpart via the relationships

$$
\alpha=-\sigma \ln [(1-\phi) / \phi], \quad \beta=\sigma, \quad u_{t}=-\sigma \ln \left(v_{t} / \varepsilon_{t}\right)
$$

Notice that eq. (5) is a theoretical demand equation, whereas eq. (1) is an empirical equation describing the equilibrium quantities and prices. Just like the classical 
supply-and-demand simultaneous equation model, interpreting eq. (1) as the demand equation requires identification assumption. In general, to identify the demand equation, we need variability from the supply side and the demand side should be relatively stable. Since the supply side has to do with production which is subject to technological improvement, it is reasonable to expect the quantity supplied series should be highly persistent which can be modeled as a stochastic trend. The demand side, on the other hand, has to do with taste and it is reasonable to expect preference shocks are relatively stable in comparison with technological shocks. In the context of demand analysis, Ogaki (1992) has shown formally that the assumptions of stable preferences and a stochastic trend in the quantity supplied are sufficient to ensure identification of a cointegrating demand equation like eq. (1).

In the theoretical analyses of Bailey (1971) and Barro (1981), followed by the empirical work of Kormendi (1983), Aschauer (1985), Evans and Karras (1996), among many others, the effective consumption is specified as a weighted average of private and government consumption:

$$
C_{t}^{*}=C_{t}+\theta G_{t}
$$

In this setup each unit of government goods is equivalent to $\theta$ units of private goods, irrespective of the current consumption level of the two goods. In other words, the indifference curves for the two goods are linear which corresponds to the extreme case of $\sigma=+\infty$ in the CES aggregator function in eq. (3). Clearly this is an empirically restrictive assumption, albeit a convenient one for analytical tractability. 


\section{Government expenditures in East Asia}

Table 1 reports a summary of the government expenditures by economic type (in percentage of GDP) for the Asian countries studied in this paper, together with the corresponding figures for the United States for comparison. The data source is World Bank (2004) which in turn is based on the primitive data in the IMF Government Financial Statistics Yearbook. Total government outlays comprise of government purchase of goods and services, wages and salaries for government employees, public capital investment, transfer payments, and interest payments of outstanding government debts. In terms of total outlays, the governments of the Asian countries are comparable in size to that of the United States, except for the Malaysia government which stands out as the outlier of the group. The pattern of government expenditures among the Asian countries is more heterogeneous. Japan and Korea seem to differ from the rest of the Asian countries and their government expenditure patterns are broadly comparable to that of the United States. The governments of Hong Kong and the five ASAEN countries, on the other hand, spend relatively more on goods and services and on government employee payroll. Table 1 also reveals that the Asian governments devote considerable amount of resources on capital investments, presumably most are on public infrastructure and, for the five ASEAN countries, also on national enterprises. This is in sharp contrast to the United States in which public investment is only $1 \%$ of GDP. Among the heavy public investors, the Indonesian government stands out as the largest by devoting $6.9 \%$ of GDP to public investment, followed by Thailand (6.5\%), Singapore (5.0\%), and Malaysia (4.8\%). Another noteworthy component is transfer payments. The transfer payments of 
the Asian governments are all relatively low comparing with the corresponding US figure of $12.3 \%$, with Japan and Korea register the highest government transfers in the 8 to $9 \%$ range and Thailand reports the lowest transfers of only $1.3 \%$ of GDP. Clearly the low transfers in the ASEAN countries and Hong Kong reflect the relatively under-developed social security system and other formal welfare schemes.

Insert Table 1 here

\section{Empirical results}

We use annual data for 1960-2002 from the World Development Indicators

(World Bank, 2004) whenever possible to ensure cross-country compatibility. Missing or erroneous entries are reconstructed from local sources. Private and government consumption are taken to be the relevant expenditure series from the National Income and Product Accounts (NIPA). The consumption ratio, $C_{t} / G_{t}$, is calculated from the constant price private and government consumption series. The two price series, $P_{t}^{g}$ and $P_{t}^{c}$, are simply the respective implicit price deflators constructed by dividing the nominal series by the constant price counterpart.

Insert Figure 1 here

Insert Table 2 here 
We begin by examining the time series properties of the log consumption ratio series, $\ln \left(C_{t} / G_{t}\right)$, and the $\log$ price ratio series, $\ln \left(P_{t}^{g} / P_{t}^{c}\right)$. Figure 1 depicts the two series for all nine Asian countries. The strong persistency and co-movements of the two series are clearly discernable from the plots, giving an initial impression that they are likely to be I(1) and cointegrated. Table 2 reports formal panel unit root test results. It is well known that unit root tests have low power and the problem may be even worse for our application as we have short time series. To better utilize sample information, we pool the nine countries' data to perform panel unit root tests, which have been shown to be more powerful than the individual time series version. All three panel unit root tests draw the same conclusion: the unit root null hypothesis is not rejected for the level series but is strongly rejected for the first-differenced series. This shows that the log consumption ratio and the log price ratio series are indeed I(1). Moreover, the asymmetry of the p-values for the level series in the IPS test and the ADF-Fisher chi-square test suggest that log consumption ratio is the less integrated series - in the sense that it has a weaker random walk component - than the log price ratio. This has important implications to the specification of the cointegrating regression. It is well known that cointegrating regression is not invariant to normalization choice - deciding which variable to put on the left hand side as the regressand - and different choices may imply different estimates for the same parameter. For example, instead of running regression eq. (1), we could have run the reverse regression with the log price ratio normalized as the regressand to obtain an estimate of $(1 / \beta)$. In finite sample the estimates from the direct and reverse regressions may be far from being reciprocal to each other and they can also have drastically different statistical properties. According to $\mathrm{Ng}$ and Perron (1997), in the 
context of cointegrating regression, it is preferable to put the less integrated series as the regressand and the more integrated series as the regressor. Applying the $\mathrm{Ng}-$ Perron rule, this means that designating the log consumption ratio series as the regressand as in eq. (1) is indeed the right choice.

\section{Insert Table 3 here}

Table 3 reports panel estimation results for eq. (1) with country specific fixed effects. The cointegration property of eq. (1) is confirmed by the two panel cointegration tests: the null hypothesis of no cointegration is decisively rejected by Kao's (1999) ADF test but the null of cointegration cannot be rejected according to the McCoskey and Kao (1998) LM test. Turning to the elasticity of substitution between private and government consumption - the coefficient of $\ln \left(P_{t}^{g} / P_{t}^{c}\right)$ - it can be seen that the estimates are all significantly positive, ranging between 0.57 and 1.05 with small standard errors, and varying across different estimation methods and sample periods. The empirical results suggest that on average private and government consumption in East Asia are substitutes with an elasticity of substitution midway between 0.5 and 1 .

We also estimate an unrestricted version of eq. (1) as a simple specification check:

$$
\ln \left(C_{t} / G_{t}\right)=\alpha+\beta_{1} \ln \left(P_{t}^{g}\right)+\beta_{2} \ln \left(P_{t}^{c}\right)+u_{t}
$$

Eq. (1) is a restricted version of eq. (8) with $\beta_{1}+\beta_{2}=0$. Estimates of $\beta_{1}$ and $\beta_{2}$ that are similar in magnitude but opposite in sign provide evidence in favor of the restriction and 
hence eq. (1). As can be seen from Table 3, the pattern of the parameter estimates is in general supportive of eq. (1); and the evidence is especially strong when all nine Asian countries are included in the sample for the period 1978-2002 (Panel B). According to the fully efficient DOLS estimates, government and private consumption in East Asia during 1978-2002 have a substantial degree of substitutability with an elasticity of substitution around 1, implying a Cobb-Douglas aggregator function for eq. (3).

From a policy perspective, the panel estimate may not be of much practical relevance, as it tells us little about any individual country. Table 4 therefore reports cointegrating regression results for the nine Asian countries individually. We also report the corresponding results for the United States for comparison. To check robustness, we try three different estimation methods which are all asymptotically efficient procedures for estimating cointegration regressions. The three methods are Phillips and Hansen (1990) fully modified ordinary least square (FM-OLS), Park (1992) canonical cointegrating regression (CCR), and Stock and Watson (1993) dynamic ordinary least squares (DOLS). In general the parameter estimates are stable across the three estimation methods. Comparing the DOLS estimates of the elasticity of substitution across countries, Malaysia and Thailand come up with the highest values of 1.66 and 1.51, respectively, which are comparable to the value of 1.5 of the United States. On the other extreme are Indonesia and Singapore for which the negative elasticities of substitution of -0.92 and -1.76 , respectively, imply that private and government consumption are strong complements. The four North East Asian countries, China, Hong Kong, Japan, and Korea, share a moderate elasticity of substitution ranging from 0.41 in Hong Kong to 0.65 in China. The Philippines, on the other hand, has a numerically small and statistically 
insignificant elasticity of substitution of 0.07 , indicating little substitution in private and government consumption.

\section{Insert Table 4 here}

Indonesia and Thailand provide an interesting case of contrast. The estimated elasticity of substitution between private and government consumption is -0.92 for Indonesia and 1.51 for Thailand. Government consumption is a strong substitute to private consumption in Thailand, implying that a fiscal contraction that makes government goods relatively more expensive will induce substantial expansion in private consumption, thereby offsetting or even outweighing the negative impact of the fiscal contraction on aggregate demand. The Indonesian government consumption, in contrast, is a strong complement to private consumption, implying that a fiscal contraction that makes government goods relatively more expensive will generate a large negative income effect that outweighs the substitution effect, leading to a concomitant contraction in private consumption expenditure that further depresses aggregate demand. These predictions about the two economies' reaction to fiscal austerity seem to be consistent with what have been observed during the 1997 Asian financial crisis.

Insert Table 5 here

What explains the cross-country diversity in the substitution between private and government consumption? In their international study, Evans and Karras (1996) find a 
statistically significant negative relationship between the share of government expenditure that goes to national defense and the degree of substitutability between private and government consumption. The idea is that the higher is the defense share, the higher is the public goods component in government consumption which reduces its ability to substitute for private consumption. In Table 5 we collect together for the nine East Asia countries their national defense expenditure shares, education expenditure shares, and estimated elasticities of substitution between private and government consumption. The entries are sorted by the substitution elasticities for ease of comparison. Apparently neither the education share nor the defense share can explain the empirical pattern of the substitution elasticities for all nine countries. However, the correlation between the defense shares and substitution elasticities is -0.24 , confirming the empirical findings of Evans and Karras (1996). The strong complementarity between private and government consumption in Singapore seems to be testimonial to the Evans-Karras story, in view of the favorable international ratings of the Singaporean education system and other infrastructure, and the government's well documented role in the country's economic success (e.g. Low (1998) and Krause et al. (1987)). The case of Indonesia may appear to be defiant of the Evans-Karras explanation: the expenditures on education and defense are only moderate and yet private and government consumption appear to be complements, according to the negative sign of the substitution elasticity. One potential explanation is the well known fact that the Indonesian government heavily subsidies the private sector including fuel, electricity, fertilizer and other basic goods, and these subsidies are complementary to other goods in the private consumption bundle; see for example Hill $(1996,1999)$ and World Bank (2006). When the Indonesian government 
adjusts these subsidies in tandem with the overall government spending, this will generate the observed co-movements of private and government consumption that gives rise to the estimated negative elasticity of substitution.

\section{Conclusion}

In this paper we have estimated the degree of substitution between private and government consumption in nine East Asia countries. On average there is substantial substitutability between private and government consumption, implying there will be direct crowding out of private consumption by government consumption. Such direct crowding out effect will reinforce the conventional interest rate and wealth effect crowding out channels to make fiscal policy relatively ineffective in East Asia. We also find that the substitutability between private and government consumption varies among the Asian countries. Government and private consumption turn out to be complements in Indonesia and Singapore, but they are substitutes in other Asian countries with different degrees of substitutability. There is no obvious quantitative variable that can explain each country's empirical estimates, although the share of government expenditure that goes to education and national defense seems to be negatively correlated with substitutability. Future study on this issue will need a more careful examination of each country's institutional details - one will have to understand what sort of government services those public consumption figures represent - before further conclusion can be drawn. 


\section{References}

Aiyagari, Rao, Lawrence Christiano and Martin Eichenbaum. 1992. The output, employment and interest effect of government consumption. Journal of Monetary Economics 30: 73-86.

Amano, Robert A. and Tony S. Wirjanto. 1997. Intratemporal substitution and government spending. Review of Economics and Statistics 79: 605-609.

Amano, Robert A. and Tony S. Wirjanto. 1998. Government expenditures and the permanent-income model. Review of Economic Dynamics 1: 719-730.

Aschauer, David. 1985. Fiscal policy and aggregate demand. American Economic Review 75 (1): 117-127.

Bailey, Martin J. 1971. National Income and the Price Level: A Study in Macroeconomic Theory. 2nd Edition. New York: McGraw-Hill.

Barro, Robert J. 1981. Output effects of government purchases. Journal of Political Economy 89 (6): 1086-1121.

Baxter, M. and Robert G. King. 1993. Fiscal policy in general equilibrium. American Economic Review 83: 343-350.

Devereux, Michael, Allen Head and Beverly Lapham. 1996. Monopolistic competition, increasing returns, and the effects of government spending. Journal of Money, Credit, and Banking 28: 233-254.

Ganelli, Giovanni. 2003. Useful government spending, direct crowding-out and fiscal policy interdependence. Journal of International Money and Finance 22: 87-103. 
Chiang, Min-Hsien and Chihwa Kao. 2002. Nonstationary panel time series using NPT 1.3 - A user guide. Center for Policy Research, Syracuse University.

Chiu, Ru-Lin. 2001. The intratemporal substitution between government spending and private consumption: empirical evidence from Taiwan. Asian Economic Journal 15 (3): $313-323$.

Evans, Paul and Georgios Karras. 1996. Private and government consumption with liquidity constraints. Journal of International Money and Finance 15 (2): 255-266.

Fiorito, Riccardo and Tryphon Kollintzas. 2004. Public goods, merit goods, and the relation between private and government consumption. European Economic Review 48: $1367-1398$.

Hill, Hal. 1996. The Indonesian Economy. Cambridge University Press.

Hill, Hal. 1999. The Indonesian Economy in Crisis: Causes, Consequences and Lessons. Singapore: Institute of Southeast Asian Studies.

Ho, Tsung-wu. 2001. The government spending and private consumption: a panel cointegration analysis. International Review of Economics and Finance 10: 95-108.

Im, Kyung So, M. Hashem Pesaran and Yongcheol Shin. 2003. Testing for unit roots in heterogeneous panels. Journal of Econometrics 115 (1): 53-74.

Kao, Chihwa. 1999. Spurious regression and residual-based tests for cointegration in panel data. Journal of Econometrics 90 (1): 1-44.

Kao, Chihwa and Min-Hsien Chiang. 2000. On the estimation and inference of a cointegrated regression in panel data. Advances in Econometrics 15: 179 - 222.

Karras, Georgios. 1994. Government spending and private consumption: some international evidence. Journal of Money, Credit, and Banking 26 (1): 9-22. 
Kormendi, Roger. 1983. Government debt, government spending, and private sector behavior. American Economic Review 73 (5): 994-1010.

Krause, Lawrence, Koh Ai Tee and Lee (Tsao) Yuan. 1987. The Singapore Economy Reconsidered. Singapore: Institute of Southeast Asian Studies.

Low, Linda. 1998. The Political Economy of a City-State: Government-made Singapore. Singapore: Oxford University Press.

Maddala, G.S. and S. Wu. 1999. A comparative study of unit root tests with panel data and a new simple test. Oxford Bulletin of Economics and Statistics 61: 631-652.

McCoskey, S. and Chihwa Kao. 1998. A residual-based tests of the null of cointegration in panel data. Econometric Review 17: 57-84.

$\mathrm{Ng}$, Serena and Pierre Perron. 1997. Estimation and inference in nearly unbalanced nearly cointegated systems. Journal of Econometrics 79 (1): 53-81.

$\mathrm{Ni}$, Shawn. 1995. An empirical analysis on the substitutability between private consumption and government purchases. Journal of Monetary Economics 36: 593-605.

Ogaki, Masao. 1992. Engle's law and cointegration. Journal of Political Economy 100 (5): 1027-1046.

Ogaki, Masao and Joon Y. Park. 1997. A cointegration approach to estimating preference parameters. Journal of Econometrics 82 (1): 107-134.

Ogaki, Masao and Carman M. Reinhart. 1998. Measuring intertemporal substitution: the role of durable goods. Journal of Political Economy 106 (5): 1078-1098.

Okubo, Masakatsu. 2003. Intratemporal substitution between private and government consumption: the case of Japan. Economic Letters 79: 75-81.

Park, Joon Y. 1992. Canonical cointegrating regression. Econometrica 60: 119-143. 
Phillips, Peter C.B. and Bruce Hansen. 1990. Statistical inference in instrumental variables regression with I(1) processes. Review of Economic Studies 57: 99-125.

Stock, James and Mark Watson. 1993. A simple estimator of cointegrating vectors in higher order integrated systems. Econometrica 61 (4): 783-820.

World Bank. 1997. World Development Report 1997 - The State in a Changing World. Oxford University Press.

World Bank. 2004. World Development Indicators 2004 CD-ROM. Washington D.C.: World Bank.

World Bank. 2006. Investing for Growth and Recovery: The World Bank Brief for the Consultative Group on Indonesia. Washington D.C.: World Bank. 
Table 1: Government expenditure by economic type 1991-2000 (\% of GDP)

\begin{tabular}{|c|c|c|c|c|c|c|}
\hline & $\begin{array}{l}\text { Goods } \\
\text { and } \\
\text { services }\end{array}$ & $\begin{array}{l}\text { Wages and } \\
\text { salaries }\end{array}$ & $\begin{array}{l}\text { Interest } \\
\text { payments }\end{array}$ & $\begin{array}{l}\text { Subsidies } \\
\text { and other } \\
\text { current } \\
\text { transfers }\end{array}$ & $\begin{array}{l}\text { Capital } \\
\text { expenditure }\end{array}$ & Total \\
\hline \multicolumn{7}{|l|}{ NE Asia } \\
\hline Hong Kong & 7.2 & 4.4 & 0.0 & 4.7 & 4.2 & 20.5 \\
\hline Japan & \multicolumn{2}{|c|}{$-2.3-$} & 3.1 & 9.0 & 2.5 & 16.9 \\
\hline Korea & 5.1 & 2.2 & 0.5 & 8.2 & 2.9 & 18.9 \\
\hline \multicolumn{7}{|l|}{ SE Asia } \\
\hline Indonesia & 4.1 & 2.3 & 2.1 & 3.9 & 6.9 & 19.3 \\
\hline Malaysia & 10.6 & 6.5 & 3.7 & 5.0 & 4.8 & 30.6 \\
\hline Philippines & 9.2 & 5.6 & 4.4 & 2.8 & 2.5 & 24.5 \\
\hline Singapore & 9.8 & 5.0 & 1.3 & 2.4 & 5.0 & 23.4 \\
\hline Thailand & 9.4 & 5.4 & 0.7 & 1.3 & 6.5 & 23.4 \\
\hline USA & 5.0 & 1.9 & 3.1 & 12.3 & 1.0 & 23.3 \\
\hline \\
\hline $\begin{array}{l}\text { Figures are } \\
\text { Malaysia (1) } \\
\text { Data source: } \\
\text { compiled fro } \\
\text { c For Japan, th } \\
\text { components. }\end{array}$ & $\begin{array}{l}\text { nnual aver } \\
\text { 91-97). } \\
\text { World Bar } \\
\text { m the Hon } \\
\text { le figure for }\end{array}$ & $\begin{array}{l}\text { (2004) for cc } 1991-2( \\
\text { Kong Annual } \\
\text { goods-and-se }\end{array}$ & $\begin{array}{l}00 \text {, except } \mathrm{f} \\
\text { untries other } \\
\text { Digest of Stc } \\
\text { vices and } \mathrm{w}\end{array}$ & $\begin{array}{l}\text { Japan (1981 } \\
\text { tan Hong K } \\
\text { stics, variou } \\
\text { es-and-salc }\end{array}$ & $\begin{array}{l}\text { 90), Korea (19 } \\
\text { g. Hong Kong } \\
\text { years. } \\
\text { es is the sum }\end{array}$ & $\begin{array}{l}-97) \text { and } \\
\text { gures are } \\
\text { the two }\end{array}$ \\
\hline
\end{tabular}


Table 2: Panel unit root tests

\begin{tabular}{lllll}
\hline & $\ln (C / G)$ & $\Delta \ln (C / G)$ & $\ln \left(P_{g} / P_{c}\right)$ & $\Delta \ln \left(P_{g} / P_{c}\right)$ \\
\hline IPS W-statistic & 0.6551 & 15.2985 & 0.6002 & 14.0852 \\
& {$[0.2562]$} & {$[0.0000]$} & {$[0.7258]$} & {$[0.0000]$} \\
ADF - Fisher & 20.3887 & 196.183 & 15.7766 & 178.734 \\
Chi-square & {$[0.3114]$} & {$[0.0000]$} & {$[0.6081]$} & {$[0.0000]$} \\
PP - Fisher & 18.0178 & 262.871 & 18.6922 & 270.737 \\
Chi-square & {$[0.4545]$} & {$[0.0000]$} & {$[0.4110]$} & {$[0.0000]$}
\end{tabular}

Notes:

a $\mathrm{P}$-values in parentheses

${ }^{\text {b }} \mathrm{H}_{0}$ : Each country follows an Individual unit root process.

$\mathrm{H}_{1}$ : At least one country's process is trend stationary

${ }^{c}$ Exogenous variables: individual effects, individual linear trends

d Cross-sectional units: China, Hong Kong, Indonesia, Japan, Korea, Malaysia, Philippines, Singapore, Thailand

e Time period: China 1978-2002; other countries 1960-2002.

${ }^{\mathrm{f}}$ IPS = Im, Pesaran and Shin (2003). ADF-Fisher and PP-Fisher are Maddala and Wu (1999) Fisher-type tests constructed by combining the p-values from individual augmented DickeyFuller (ADF) and Phillips-Perron (PP) unit-root tests. 
Regressand: $\ln \left(C_{t} / G_{t}\right)$

Panel A: 8 Asian countries (exclude China) 1960-2002

\begin{tabular}{|c|c|c|c|c|c|}
\hline & \multicolumn{3}{|c|}{ Regressors } & \multicolumn{2}{|c|}{ Cointegration Test } \\
\hline & $\ln \left(P_{t}^{g} / P_{t}^{c}\right)$ & $\ln \left(P_{t}^{g}\right)$ & $\ln \left(P_{t}^{c}\right)$ & $\mathrm{ADF}$ & LM \\
\hline OLS & $\begin{array}{l}0.5722 \\
(0.0614)\end{array}$ & & & $\begin{array}{l}-5.5516 \\
{[0.0000]}\end{array}$ & $\begin{array}{l}0.6516 \\
{[0.2573]}\end{array}$ \\
\hline OLS & & $\begin{array}{l}0.7975 \\
(0.0639)\end{array}$ & $\begin{array}{c}-0.8847 \\
(0.0698)\end{array}$ & $\begin{array}{c}-4.3753 \\
{[0.0000]}\end{array}$ & $\begin{array}{l}2.4090 \\
{[0.0080]}\end{array}$ \\
\hline DOLS & $\begin{array}{l}0.7555 \\
(0.0651)\end{array}$ & & & & \\
\hline DOLS & & $\begin{array}{l}1.0132 \\
(0.0607)\end{array}$ & $\begin{array}{l}-1.1132 \\
(0.0646)\end{array}$ & & \\
\hline
\end{tabular}

Panel B: 9 Asian countries (include China) 1978-2002

Regressors

\begin{tabular}{llllll} 
& \multicolumn{2}{c}{ ADF } & Cointegration Test \\
\hline OLS & $\ln \left(P_{t}^{g} / P_{t}^{c}\right)$ & $\ln \left(P_{t}^{g}\right)$ & $\ln \left(P_{t}^{c}\right)$ & AD & \\
& 0.6373 & & & -6.8337 & 0.5369 \\
& $(0.1064)$ & & {$[0.0000]$} & {$[0.2957]$}
\end{tabular}

$\begin{array}{lllll}\text { OLS } & 0.5958 & -0.5718 & -6.7290 & 0.4498 \\ & (0.1361) & (0.1709) & {[0.0000]} & {[0.3264]}\end{array}$

DOLS $\quad 1.0589$

(0.0999)

DOLS

$\begin{array}{ll}0.9740 & -0.9073 \\ (0.1250) & (0.1591)\end{array}$

Notes:

a Standard errors in parentheses

${ }^{\mathrm{b}} \mathrm{P}$-values in square brackets

c All regressions include country-specific fixed effect (unreported)

${ }^{\mathrm{d}}$ DOLS = Kao and Chiang (2000) panel dynamic OLS. The regression is augmented with one lead and one lag of the first difference of the regressors (unreported).

e $\mathrm{ADF}=\mathrm{Kao}$ (1999) panel ADF test for the null hypothesis of no cointegration. The lag length in the test regression is chosen by the Schwarz criterion.

${ }^{\mathrm{f}} \mathrm{LM}=$ McCoskey and Kao (1998) panel LM test for the null hypothesis of cointegration 
Table 4: Individual cointegrating regressions

\begin{tabular}{|c|c|c|c|c|c|c|}
\hline \multirow{3}{*}{$\begin{array}{c}\text { NE Asia } \\
\text { China }\end{array}$} & \multicolumn{2}{|c|}{ FM-OLS } & \multicolumn{2}{|c|}{ CCR } & \multicolumn{2}{|c|}{ DOLS } \\
\hline & intercept & $\ln \left(P_{t}^{g} / P_{t}^{c}\right)$ & intercept & $\ln \left(P_{t}^{g} / P_{t}^{c}\right)$ & intercept & $\ln \left(P_{t}^{g} / P_{t}^{c}\right)$ \\
\hline & $\begin{array}{l}1.3334 \\
(0.0161)\end{array}$ & $\begin{array}{l}0.6699 \\
(0.1452)\end{array}$ & $\begin{array}{l}1.3335 \\
(0.0161)\end{array}$ & $\begin{array}{l}0.6691 \\
(0.1513)\end{array}$ & $\begin{array}{l}1.3526 \\
(0.0216)\end{array}$ & $\begin{array}{l}0.6524 \\
(0.2136)\end{array}$ \\
\hline Hong Kong & $\begin{array}{l}1.8645 \\
(0.0245)\end{array}$ & $\begin{array}{l}0.3242 \\
(0.0556)\end{array}$ & $\begin{array}{l}1.8656 \\
(0.0259)\end{array}$ & $\begin{array}{l}0.3269 \\
(0.0575)\end{array}$ & $\begin{array}{l}1.8772 \\
(0.0260)\end{array}$ & $\begin{array}{l}0.3424 \\
(0.0468)\end{array}$ \\
\hline Japan & $\begin{array}{l}1.3063 \\
(0.0204)\end{array}$ & $\begin{array}{l}0.2962 \\
(0.1026)\end{array}$ & $\begin{array}{l}1.3064 \\
(0.0192)\end{array}$ & $\begin{array}{l}0.2986 \\
(0.0758)\end{array}$ & $\begin{array}{l}1.3329 \\
(0.0119)\end{array}$ & $\begin{array}{l}0.4149 \\
(0.0780)\end{array}$ \\
\hline Korea & $\begin{array}{l}1.6748 \\
(0.0297)\end{array}$ & $\begin{array}{l}0.5770 \\
(0.0594)\end{array}$ & $\begin{array}{l}1.6755 \\
(0.0300)\end{array}$ & $\begin{array}{l}0.5778 \\
(0.0591)\end{array}$ & $\begin{array}{l}1.6468 \\
(0.0177)\end{array}$ & $\begin{array}{l}0.5233 \\
(0.0331)\end{array}$ \\
\hline $\begin{array}{l}\text { SE Asia } \\
\text { Indonesia }\end{array}$ & $\begin{array}{l}1.8534 \\
(0.1038)\end{array}$ & $\begin{array}{l}-0.9809 \\
(0.5449)\end{array}$ & $\begin{array}{l}1.8574 \\
(0.1030)\end{array}$ & $\begin{array}{c}-0.9273 \\
(0.5090)\end{array}$ & $\begin{array}{l}1.8613 \\
(0.0449)\end{array}$ & $\begin{array}{c}-0.9243 \\
(0.2614)\end{array}$ \\
\hline Malaysia & $\begin{array}{l}1.3427 \\
(0.0255)\end{array}$ & $\begin{array}{l}1.6028 \\
(0.3979)\end{array}$ & $\begin{array}{l}1.3421 \\
(0.0257)\end{array}$ & $\begin{array}{l}1.6218 \\
(0.4106)\end{array}$ & $\begin{array}{l}1.3420 \\
(0.0193)\end{array}$ & $\begin{array}{l}1.6601 \\
(0.3488)\end{array}$ \\
\hline Philippines & $\begin{array}{l}2.2307 \\
(0.0423)\end{array}$ & $\begin{array}{l}0.0458 \\
(0.1288)\end{array}$ & $\begin{array}{l}2.2334 \\
(0.0421)\end{array}$ & $\begin{array}{l}0.0328 \\
(0.1333)\end{array}$ & $\begin{array}{l}2.2179 \\
(0.0361)\end{array}$ & $\begin{array}{l}0.0707 \\
(0.1207)\end{array}$ \\
\hline Singapore & $\begin{array}{l}1.4852 \\
(0.0556)\end{array}$ & $\begin{array}{c}-1.9452 \\
(0.4855)\end{array}$ & $\begin{array}{l}1.4836 \\
(0.0563)\end{array}$ & $\begin{array}{l}-1.9716 \\
(0.5069)\end{array}$ & $\begin{array}{l}1.4933 \\
(0.0371)\end{array}$ & $\begin{array}{l}-1.7679 \\
(0.3586)\end{array}$ \\
\hline Thailand & $\begin{array}{l}1.7239 \\
(0.0684)\end{array}$ & $\begin{array}{l}1.3858 \\
(0.5139)\end{array}$ & $\begin{array}{l}1.7241 \\
(0.0646)\end{array}$ & $\begin{array}{l}1.3841 \\
(0.4778)\end{array}$ & $\begin{array}{l}1.7057 \\
(0.0440)\end{array}$ & $\begin{array}{l}1.5149 \\
(0.3447)\end{array}$ \\
\hline USA & $\begin{array}{l}1.4284 \\
(0.0291)\end{array}$ & $\begin{array}{l}1.5373 \\
(0.2304)\end{array}$ & $\begin{array}{l}1.4298 \\
(0.0292)\end{array}$ & $\begin{array}{l}1.5155 \\
(0.1677)\end{array}$ & $\begin{array}{l}1.3818 \\
(0.0184)\end{array}$ & $\begin{array}{l}1.5078 \\
(0.1642)\end{array}$ \\
\hline
\end{tabular}

Notes:

${ }^{a}$ Standard errors in parentheses

b Time period: China 1978-2002; other countries 1960-2002.

${ }^{c}$ FM-OLS = Fully modified OLS; CCR = Canonical cointegrating regression; DOLS = Dynamic OLS. FM-OLS and CCR use Andrews' automatic bandwidth selection method in computing the long run variance matrix. DOLS includes one lead and one lag of the first difference of the regressors in the augmented regression. 
Table 5: Government expenditures and substitutability

\begin{tabular}{|c|c|c|c|c|}
\hline & $\begin{array}{l}\text { (1) } \\
\text { Education } \\
(\% \text { of }\end{array}$ & $\begin{array}{l}\text { (2) } \\
\text { Defense } \\
\text { enditure) }\end{array}$ & $(1)+(2)$ & $\begin{array}{l}\text { (4) } \\
\text { Elasticity of Substitution } \\
\text { (DOLS estimate) }\end{array}$ \\
\hline Singapore & 21.0 & 26.5 & 47.5 & -1.76 \\
\hline Indonesia & 9.8 & 6.6 & 16.4 & -0.92 \\
\hline Philippines & 15.7 & 10.5 & 26.2 & 0.07 \\
\hline Hong Kong & 14.5 & 0.0 & 14.5 & 0.34 \\
\hline Japan & 6.2 & 4.4 & 10.6 & 0.41 \\
\hline Korea & 18.8 & 20.0 & 38.8 & 0.52 \\
\hline China & 2.4 & 16.3 & 18.7 & 0.65 \\
\hline Thailand & 21.3 & 15.6 & 36.9 & 1.51 \\
\hline Malaysia & 20.4 & 11.7 & 32.1 & 1.66 \\
\hline $\begin{array}{l}\text { Correlation } \\
\text { with (4) }\end{array}$ & 0.07 & -0.24 & -0.12 & \\
\hline \multicolumn{5}{|c|}{$\begin{array}{l}\text { Notes: } \\
\text { a } \text { The reported expenditure figures are annual average of 1991- } 95 \text {. } \\
\text { b } \text { Data source: World Bank (2004) for countries other than Hong Kong. Hong Kong } \\
\text { figures are compiled from the Hong Kong Annual Digest of Statistics, various years. }\end{array}$} \\
\hline
\end{tabular}


Figure 1
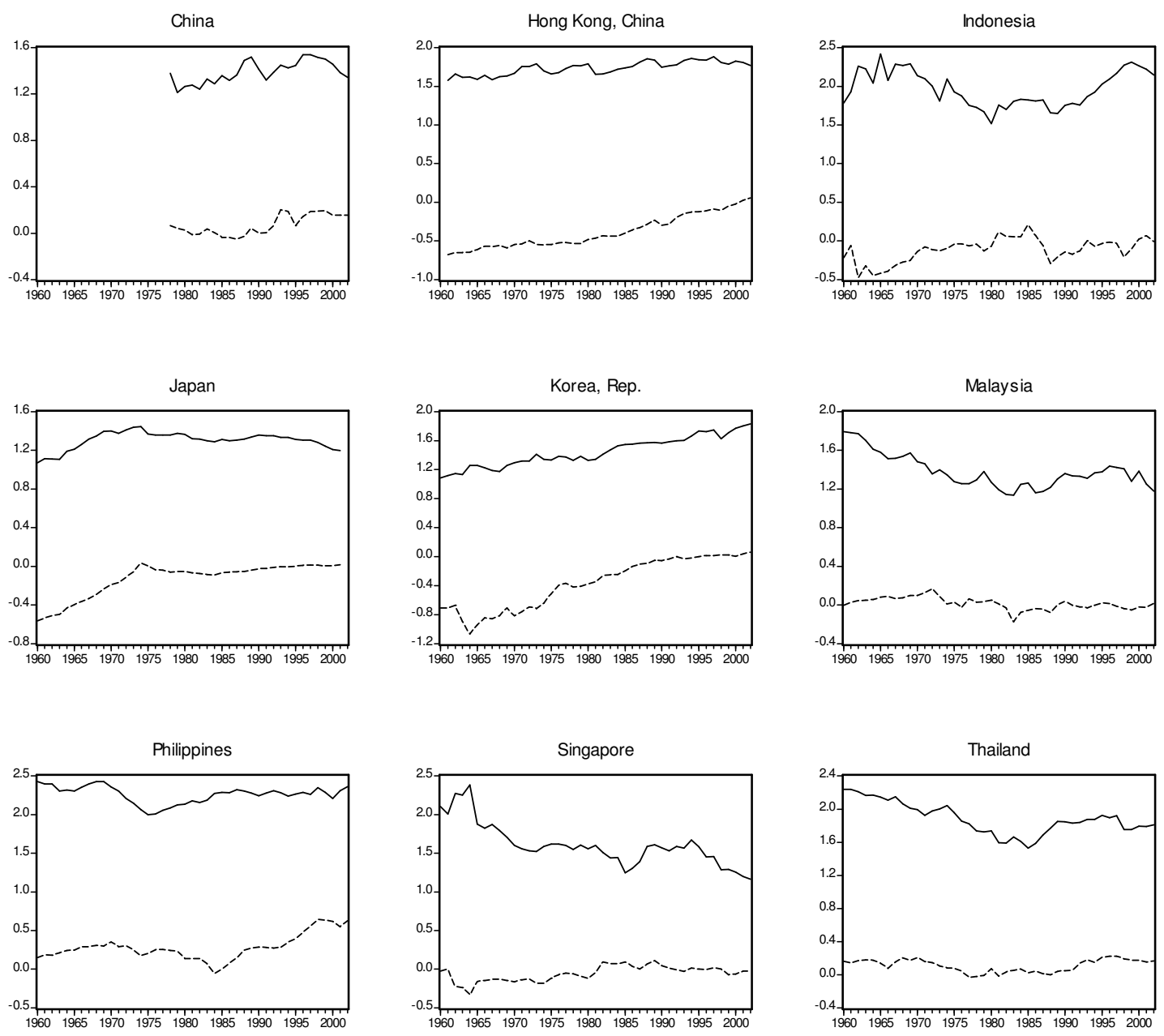

Solid $=\log$ consumption ratio $\ln \left(C_{t} / G_{t}\right)$

Dashed $=\log$ price ratio $\ln \left(P_{t}^{g} / P_{t}^{c}\right)$ 